\title{
"Our Silence Buys the Battles": The Role of Protest Music in the U.S.-Central American Peace and Solidarity Movement
}

\author{
CARA E. PALMER
}

\author{
"No más! No more!" \\ Shout the hills of Salvador \\ Echo the mountains of Virginia \\ We cry out "No más! No more!"
}

\author{
"No más! No more!" \\ Shout the hills of Salvador \\ In Guatemala, Nicaragua \\ We cry out "No más! No more!"
}

In the 1980s, folk singer John McCutcheon implored his fellow U.S. citizens to stand in solidarity with Central Americans in countries facing United States (U.S.) intervention. Combining both English and Spanish words, his song "No Más!" exemplifies the emphasis on solidarity that characterized the dozens of protest songs created in connection with the U.S.-Central American Peace and Solidarity Movement (CAPSM). ${ }^{2}$ McCutcheon's song declared to listeners that without their active opposition, the U.S. government would continue to sponsor violence for profit. McCutcheon sang, "Our silence buys the battles, let us cry, 'No más! No more!," urging listeners to voice their disapproval of the Reagan administration's foreign policies, because remaining silent would result in dire consequences.

One hundred thousand U.S. citizens mobilized in the 1980s to protest U.S. foreign policy toward Central America. They pressured Congress to end U.S. military and financial aid for the military junta in El Salvador, the military dictatorship in Guatemala, and the Contras in Nicaragua. The Reagan administration supported armed government forces in El Salvador and Guatemala in their repression of the armed leftist groups FMLN and MR-13, and the Contras in Nicaragua in their war against the successful leftist revolution led by the FSLN. The repression translated to human rights violations against the civilian populations, with U.S.-backed forces carrying out illegal arrests, disappearances, tortures, and extrajudicial killings, and, in the case of Guatemala, genocide against the indigenous population. ${ }^{3}$

CAPSM, largely begun and sustained by Guatemalan, Nicaraguan, and Salvadoran immigrants and exiles living and seeking amnesty in the United States, operated through a transnational network of activists. Revolutionaries in Central America and activists in the United States utilized what Latin

\footnotetext{
${ }^{1}$ John McCutcheon, “No Más!” Water from Another Time, Rounder, 1989, MP3.

${ }^{2}$ Scholars have employed several different titles for this movement. I choose the terminology of Latin American Studies scholar Hector Perla Jr. because it emphasizes the transnational character of the movement with its reference to the involvement of U.S. citizens and Central Americans, and its inclusion of "solidarity," an important theme of the movement.

${ }^{3}$ Truth commissions in El Salvador (1992-1993) and Guatemala (1997-1999) attributed, respectively, ninety-five percent and ninety-three percent of human rights violations committed during the conflicts to government forces supported by the U.S. These included illegal arrests, disappearances, tortures, and extrajudicial killings, and, in the case of Guatemala, genocide against the indigenous population. Belisario Betancur, Reinaldo Figueredo Planchart, and Thomas Buergenthal, From Madness to Hope: The 12-Year War in El Salvador: Report of the Commission on the Truth for El Salvador, (1993), 12; Guatemala: Memory of Silence (Tz'inil Na'tab'al). Report of the Commission for Historical Clarification: Conclusions and Recommendations, 33.
} 
American Studies scholar Hector Perla Jr. terms a signal flare strategy: they appealed to U.S. citizens through rhetorical subversion via "witness testimonies." Their tactic - translated into that of CAPSM's leading organizations, Sanctuary, Witness for Peace, and Pledge of Resistance - was premised on the importance of witnessing human rights abuses in Central America or hearing testimony of human rights abuses from Central Americans. ${ }^{5}$ Sociologist Christian Smith writes, "Nothing so deeply disturbed and enraged so many Americans, sending them headlong into the struggle to defeat White House policy, as hearing flesh-and-blood men, women, and children tell heartrending stories of hunger, terror, disappearances, torture, executions, rape, and mass murder." ${ }^{6}$ Direct contact with the consequences of the Reagan administration's foreign policies was facilitated by Central American immigration to the United States, trips organized for U.S. citizens to visit Central American war zones and refugee camps, and the subsequent publication of hundreds of witness testimonies by both Central Americans and U.S. citizens in established newspapers and journals. Sociologist Clare Weber argues that these experiences moved U.S. citizens to engage in what she terms dissident citizen diplomacy - the "non-institutional, non-violent and sometimes illegal practices employed to change U.S. political, military and economic policy" in Central America. ${ }^{7}$

Protest music was closely tied to CAPSM's use of witness testimonies, and thus constituted an integral part of the movement. Songs like McCutcheon's "No Más!” represented an alternate form of testimony to the movement organizations' written accounts. Like written testimonies, these songs spoke of human rights violations committed by U.S.-supported regimes or counterrevolutionaries in Central America. ${ }^{8}$ I argue that protest music was integral to CAPSM for two reasons. First, its creation reflected the effectiveness of the movement's organizing strategy of using witness testimonies. Folk, punk rock, and rock artists were inspired to write and compose their protest music after being exposed to the movement's written testimonies or after traveling to Central America themselves. Second, the songs in turn became "musical testimonies" that could educate and mobilize a large audience. ${ }^{9}$ Furthermore, the creation of this protest music contradicts arguments of musical apathy during the decade. Some historians have argued that in the late 1970s, the musical style of rock subsumed the political lyrics characteristic of its predecessor, the folk music of the 1960s and 1970s; lyrical apathy ensued; and, by the 1980s, musicians themselves had become apolitical. ${ }^{10}$ However, the folk, punk rock, and rock music created in the context of and for CAPSM suggests otherwise. This music and its place in the movement continued the tradition of protest music in service to social movements in the 1950s, 1960s, and 1970s. Like its predecessors,

\footnotetext{
${ }^{4}$ Hector Perla Jr., "Si Nicaragua Venció, El Salvador Vencerá: Central American Agency in the Creation of the U.S.-Central American Peace and Solidarity Movement," Latin America Research Review 43, no. 2 (2008): 142-43.

${ }^{5}$ The Sanctuary movement began in 1980 when churches and faith-based activists illegally provided aid and refuge to Central Americans crossing the border into the U.S. fleeing political repression and violence and were refused asylum; Witness for Peace was founded in 1983 by faith-based activists responding to U.S. funding of the Contras in Nicaragua, and dedicated its efforts to sending U.S. citizens to Central America as witnesses and peacekeepers; and Pledge of Resistance was launched in 1984 by a coalition of activists opposed to what they perceived as a looming U.S. invasion of Nicaragua and advocated nonviolent direct action before its advent.

${ }^{6}$ Christian Smith, Resisting Reagan: The U.S. Central America Peace Movement (Chicago: The University of Chicago Press, 1996), 151. https://doi.org/10.7208/chicago/9780226763330.001.0001.

${ }^{7}$ Clare Weber, Visions of Solidarity: U.S. Peace Activists in Nicaragua from War to Women's Activism and Globalization (Lanham, MD: Lexington Books, 2006), 21.

${ }^{8}$ See footnote 3 .

${ }^{9}$ I have coined the term "musical testimony" to emphasize the educational value of the protest music while acknowledging its primary difference from written testimonies - the medium in which it was produced.

${ }^{10}$ Jerry Rodnitsky, “The Decline and Rebirth of Folk-Protest Music," in The Resisting Muse: Popular Music and Social Protest, ed. Ian Peddie (Burlington, VT: Ashgate, 2006), 22, 25.
} 
CAPSM inspired cross-genre creation of new protest music and then, considering it valuable, used that music to build widespread support. ${ }^{11}$

In this article, I examine six artists: the folk artists John McCutcheon and Peter, Paul and Mary; the punk rock artists M.D.C. and Toxic Reasons; and the rock artists U2 and Bruce Cockburn. Several other artists in each genre produced protest music in response to interventions in Central America, most notably the folk artists Holly Near and Joan Baez; the punk rock artists Dead Kennedys and Reagan Youth; and the rock artists The Clash and Jackson Browne. In addition, cross-national, cross-language musical influence constituted an entire segment of protest music within CAPSM, especially with regard to U.S. tours of Central American artists and Spanish-language songs popularized in the U.S., as well as collaborations between U.S. artists and Central American artists in Central America. However, the stories of the artists on whom I chose to focus illustrate the reach of CAPSM by reflecting the signal flare strategy of CAPSM, the influence of witness testimonies on their music, and the subsequent conscious use of their music by CAPSM to reach a wide audience in the U.S.

\section{0s Folk}

John McCutcheon's travels illustrate the politicizing influence of witnessing human rights abuses in Central America. He traveled to Central America, most often to Nicaragua, throughout the 1980s, befriending Central Americans who had been directly affected by the conflict and interacting and collaborating with local musicians. ${ }^{12}$ After witnessing the effects of violence in Nicaragua, he wrote "No Más!" and "Caught in the Crossfire." In the latter, McCutcheon remembered his interaction with a woman who had lost her family: "Her voice never trembled, her look never waned / As she showed me the photos in the solemn black frames / A cousin, a sister, a daughter, a son / Lost in the night or in the sight of a gun." 13 With this song, he recounted and publicized a verbal and visual testimony he himself had received, and with it created a musical testimony to transmit to listeners in the U.S. Rather than publish his testimony as a written account, he sang. McCutcheon reasoned, "People bring lots of different skills, access, and points of view to the table. As a musician, I have a microphone," and so he used it to reveal the truth of the Central American experience to the U.S. public. ${ }^{14}$

Indicating the value of music to its cause, leading CAPSM organization Witness for Peace published an ad for John McCutcheon's music in its newsletter, and the folk music magazine Sing Out! published the music and lyrics to "No Más!" 15 Sing Out! was well known among folk musicians for its publication of the music and lyrics of contemporary folk songs so that readers could learn and perform the songs themselves. ${ }^{16}$ In "No Más!" McCutcheon drew connections between violence in Central America and

\footnotetext{
${ }^{11}$ With the term "protest music," I mean to convey the following definition of sociologists Rob Rosenthal and Richard Flacks: the music "implies, suggests, or openly states that existing arrangements are not natural, normal, or eternal, but the result of previous human decisions and arrangements, and thus susceptible to change, especially if those in a similar position band together to oppose those arrangements" (italics in original). In this context, I include both "music intended by its creators, at least in part, to help support a movement" and that which incidentally has the same effect, because both assist in mobilization - moving people to action within the movement. Rob Rosenthal and Richard Flacks, Playing for Change: Music and Musicians in the Service of Social Movements (Boulder, CO: Paradigm Publishers, 2012), $20,9$.

${ }^{12}$ John McCutcheon, e-mail correspondence with author, April 29, 2014.

${ }^{13}$ John McCutcheon, "Caught in the Crossfire," Water from Another Time, Rounder, 1989, MP3.

${ }^{14} \mathrm{McCutcheon}$, e-mail correspondence with author.

15 “Nicaragua Presente! Music from Nicaragua Libre," Witness for Peace Newsletter 6, no. 4 (August/September/October 1989), 14.

${ }^{16}$ Sing Out!, originally People's Songs, was founded in 1950 by a group of folk artists that included Pete Seeger, Woody
} 
prosperity in the U.S. to bring U.S. citizens' attention to their culpability in the conflicts: "With the white hand of the death squads and the rumble of the tanks / Keeps the coffee on our tables and the money in our banks." ${ }^{17}$ By asserting the financial motive for U.S. intervention, McCutcheon challenged the Reagan administration's interventions as dishonorable and exposed consumer complicity. Both revelations were meant to inspire action on the part of U.S. citizens. Calling for solidarity with the people of Central America, McCutcheon left listeners with a vision of what the end result of that solidarity should look like: "No swords shall turn to plowshares till the land is theirs to plow / Till the name is on the ballot that rots in the prison now / And the weapons of their victory shall be schools and food and jobs / And the song from every mountain top is 'Paz y Libertad!"”18 Including the music and lyrics to songs like "No Más" in major publications contributed to the proliferation of the music and knowledge of its political context. Readers of Sing Out! found these lyrics presented in several issues, so the folk community certainly knew "No Más" and could reproduce it to inform and mobilize a widespread U.S. audience.

Protest music by the folk trio Peter, Paul and Mary, too, constituted valuable testimony. In April 1982, Sojourners Magazine, a popular monthly Christian publication, printed a special issue on the U.S. war in Central America focusing on the violence in Nicaragua and El Salvador. ${ }^{19}$ Noel "Paul" Stookey was so moved by the magazine's reportage that he wrote a song called "El Salvador." 20 The song referenced atrocities such as the 1980 death squad murders of four American churchwomen and the 1981 massacre of civilians at Rio Lempa, lifting facts right out of the articles in Sojourners. Stookey sang of the U.S. military and financial support for that violence: "They say for half a billion they could do it right / Bomb all day, burn all night / Until there's not a living thing upright / in El Salvador." ${ }^{21}$ Without traveling to El Salvador, Stookey relied on the witness testimonies published in Sojourners to inform his perspective on the conflict, and his activism in response to it. He felt the magazine conveyed the truth about the violence, and wanted to share that truth. ${ }^{22}$ Given the origins of the lyrics, Stookey credited the founder and editor of Sojourners, Jim Wallis, as co-author, illustrating his own knowledge of the impact of the witness testimony he had read in the article. He aimed to articulate his anger and sadness at the injustice in the lyrics of the song, concluding with a remark on the hypocrisy of a U.S. foreign policy rhetorically based on spreading democracy: "And kill the people to set them free / Who put this price on their liberty? / Don't you think it's time to leave / El Salvador?"23 The final question invited the listener to consider the testimonial evidence presented in the song, adopt Stookey's perspective on the conflict, and emulate his active opposition.

Stookey, Peter Yarrow, and Mary Travers began traveling to Central America the next year to witness the nature of the conflict for themselves. Travers participated in a human rights commission investigating the human rights abuses in El Salvador in 1983, having been, like Stookey, moved to action

Guthrie, and Paul Robeson. This folk music magazine, published quarterly with a circulation of about 20,000, printed songs promoting social justice. "Sing Out! History," Sing Out!, accessed April 20, 2014, http://www.singout.org/sohistry.html.

17 “No Más!” Sing Out! 31, no. 1 (January/February/March 1985), 44-45.

18 "Paz y Libertad" translates to "Peace and Freedom.” McCutcheon, "No Más!"

${ }^{19}$ Sojourners Magazine was first published in 1971 and since then has enjoyed wide circulation, reaching 1.5 million annually, and has won numerous awards from the Associated Church Press and the Evangelical Press Association, indicating its prominence among Christians in the U.S. "History," Sojourners: Faith in Action for Social Fustice, accessed April 20, 2014, http://sojo.net/about-us/history. "Media Kit," Sojourners: Faith in Action for Social fustice, accessed April 20, 2014, http://sojo.net/advertising/media-kit.

${ }^{20}$ Noel Stookey, e-mail correspondence with author, March 13, 2014.

${ }^{21}$ Peter, Paul and Mary, "E1 Salvador," No Easy Walk to Freedom, Warner Off Roster, 1986, MP3.

${ }^{22}$ Noel Stookey, interview with author, April 14, 2012.

${ }^{23}$ Peter, Paul and Mary, "El Salvador." 
by Sojourners' reports. ${ }^{24}$ Travers kept a diary during the tour and wrote, "We must declare to our allies and adversaries alike that political assassination is just not acceptable. We must declare it both in word and in deed." 25 In solidarity with their Central American allies, the trio traveled together to El Salvador and Nicaragua in 1986 with a film crew, self-funding a PBS documentary of their trip. The film included interviews with refugees who had lost family members in the conflicts, footage of military operations to which the U.S. contributed funding, training, and weapons, and audio of the group's protest music, including the song "El Salvador." 26 With witness testimonies from Central Americans and music from Peter, Paul and Mary, this film became an indispensable tool for CAPSM. It reached broad audiences through documentary film festivals and PBS broadcasting in $1987 .{ }^{27}$ Yarrow called it "an advocacy piece challenging the policies of the United States in El Salvador and Nicaragua," indicating the political intention of the film. ${ }^{28}$ Stookey had the last words on the documentary itself: "Here in Nicaragua and El Salvador, I saw the realities of what was directed by United States foreign policy, and that's not America to me. That's not what I've been singing about, and hoping about, for all these years." ${ }^{29}$ With this statement, he illustrated the point of CAPSM's signal flare strategy - to witness the consequences of U.S. intervention - and the power of the film and its music to mobilize viewers through their identification with the contradiction between the promise of U.S. ideals and its activities abroad.

Peter, Paul and Mary's experiences of reading testimony and witnessing conflict had been made possible by CAPSM organizations' signal flare strategies. The Sojourners organization was closely tied to Witness for Peace and Pledge of Resistance: Wallis co-founded both. Sojourners acted in tandem with these organizations primarily through its magazine's efforts to raise awareness about events in Central America among faith-based activists of the movement. Sojourners printed and publicized witness reports from solidarity activists who traveled to Central America with Witness for Peace and further called for signatures to the Pledge of Resistance. These tactics created the context in which Stookey wrote "El Salvador" and prompted the band to travel to Central America. Although Travers had been politically active since the time of the Civil Rights Movement, she remarked that the trip to El Salvador had changed her life. She wrote, "I had marched against the war in Vietnam, but I had never talked to the victims of human rights abuses outside of my own country." ${ }^{30}$ After seeing and talking with people in El Salvador, she became more involved in political movements against the oppression. While she underwent a transformation through direct contact with Salvadoran refugees, Stookey had initially been most affected by the written witness testimonies he had read in Sojourners Magazine.

The subsequent use by Sojourners of the song indicates an understanding of the potential of the music to recruit more activists. A review of the album on which "El Salvador" appeared emphasized the band's and Sojourners' hopes that the music would spark a renewed political consciousness in listeners, given "the strong commitment Peter, Paul and Mary have made to call their listeners to action." 31 The magazine published articles about several of Peter, Paul and Mary's albums throughout the 1980s and

\footnotetext{
${ }^{24}$ Mary Travers, "Soviet Jewry," in Mary Travers: A Woman's Words, ed. Mike Renshaw (North Charleston, SC: CreateSpace Independent Publishing Platform, 2013), 114.

${ }^{25}$ Mary Travers, "El Salvador," in Mary Travers: A Woman's Words, 100.

${ }^{26}$ Ana Carrigan, director, Heartstrings: Peter, Paul E Mary in Central America, PBS, 1987.

${ }^{27}$ William Ruhlmann, "Reunion: A Song to Sing All Over this Land," Peter Paul E Mary, 1996, 5, http://www.peterpaulandmary.com/history/f-ruhlmann5.htm.

${ }^{28}$ Ruhlmann, "Reunion."

${ }^{29}$ Carrigan, Heartstrings.

${ }^{30}$ Travers, "Soviet Jewry," 115.

${ }^{31}$ Dan Ouellette, “On the Road Again: Making History with Peter, Paul and Mary,” Sojourners 16, no. 5 (May 1987$), 51$.
} 
printed ads in multiple issues for a single record featuring "El Salvador." 32 The ad first explains that an issue of Sojourners inspired Stookey to write "El Salvador," demonstrating the impact the solidarity movement had on people who became aware of issues in Central America because of the work of the movement. Second, Sojourners promoted "El Salvador" as an "anthem for the movement against U.S. intervention in Central America," indicating that Sojourners used it as a tool to further engage readers and spread awareness of the violence and the movement against it. ${ }^{33}$ Sojourners also sold the record through their magazine as a way to obtain financial support for its work. To that same end, Stookey donated a percentage of the profits to Wallis, and Peter, Paul and Mary released a single of "El Salvador" as a fundraiser for the Sanctuary Movement. ${ }^{34}$ The band performed the song at each of their concerts, raising their fans' political consciousness and calling them to action. The fact that at times the band was booed as Stookey called for the U.S. "to leave El Salvador" speaks to the level of controversy this issue aroused in the U.S. public, but it also indicates that Peter, Paul and Mary's audience listened to the lyrics and actively chose their political positions based on the awareness those songs generated. The life of "El Salvador" therefore illustrates the power of witness testimonies to inspire action - in this case, the creation of a musical testimony - and the power of that action in turn to support the larger movement.

\section{0s Punk Rock}

Through witness testimonies, punk rock bands like M.D.C. and Toxic Reasons likewise acquired knowledge about events in Central America and likewise translated that information and their ensuing anger into their music. These bands had connections to a monthly punk rock fanzine called Maximum RocknRoll, which published reports of the underground punk rock music scene as well as news reports in which punk rock performers commented on politics and related their political convictions to their music. ${ }^{35}$ Contradicting misperceptions of punk rock as senselessly angry, the genre became increasingly political in the 1980s, and so did the magazine. Country reports detailing the music that populated different punk rock scenes were accompanied by witness reports of events in El Salvador, Guatemala, and Nicaragua. Columnists for Maximum RocknRoll made a point to discuss the magazine's identity as an alternate source of news about events in Central America: the mainstream media "can manipulate us all too easily because they know we aren't able to draw the line between their lies and their truths." ${ }^{36}$ Maximum RocknRoll attempted to combat this cycle of disinformation by publishing the reports of its own volunteer staff members who traveled to report on punk rock scenes and ended up discovering much more about the political climate of the countries they visited. The magazine further called on punk rock artists not only to be aware of the violence, but also to do something about it.

These punk rock artists used their music to promote truth and action, as the magazine did with its articles. David Dictor of M.D.C. commented on his band's motivation for writing songs protesting U.S. foreign policies toward Central America: they wanted to tell the U.S. public, "this is what's going on with

\footnotetext{
${ }^{32}$ These were: the August/September 1985, November 1985, February 1986, March 1986, June 1986, November 1986, and April 1987 issues of Sojourners.

33 "El Salvador, by Peter, Paul and Mary," Sojourners 14, no. 8 (August/September 1985), 47.

${ }^{34}$ Stookey actually attempted to ensure that royalties would go to the magazine by crediting Sojourners as co-author, but organizations are not entitled to royalties. So, he credited Wallis instead. Stookey, e-mail correspondence with author.

${ }^{35}$ Maximum RocknRoll was first published in 1982 by politically outspoken Tim Yohannan, known for his explicit insertion of left-wing politics into discussions of punk rock. The magazine enjoys wide circulation, with distributors throughout the U.S. and around the world. "About," Maximum RocknRoll, accessed April 20, 2014, http://maximumrocknroll.com/about/.

36 “Talkin' Shit with Jane,” Maximum RocknRoll 74 (July 1989), 20.
} 
your tax dollars; this is what's going on with your government. We gotta rise up and stop it, protest it, and end it." ${ }^{37}$ In particular, news of the murders of the four American churchwomen and the assassination of the Roman Catholic Archbishop of San Salvador, Oscar Romero, and commentary on these reports in Maximum RocknRoll, inspired musical testimonies. M.D.C. used the information they found in alternate media sources like Maximum RocknRoll to fuel their music. They wrote and performed songs like "Guns for Nicaragua" and "Who's the Terrorist Now?" The latter caustically condemns U.S.-sponsored violence: "Guns, planes, napalm flames / Stencil proudly our nation's name / So the dying can read who's to blame." ${ }^{38}$ Incensed by what they viewed as the U.S.'s morally reprehensible activities in other countries, punk rock bands like M.D.C. wrote and performed their music in response to reports about U.S. interventions to inform their listeners.

So, too, did Toxic Reasons. Maximum RocknRoll interviewed the band in 1983: "It's our turn in our generation to carry the weight on our shoulders and to sing the truth. Let us be heard," the band commented, remarking on the importance of conveying the reality of U.S. government activities. ${ }^{39}$ The lyrics to one of the band's songs, "How Do You Feel," accompanied the interview. They read: "How do you feel in El Salvador / With armed guerillas at your front door? / American influence in your land / American guns in their hands." ${ }^{40}$ Toxic Reasons saw their lyrics as truthful testimonies to current events, referencing details of those events to promote truth and action. Thus, the signal flare strategy permeated Toxic Reasons' music as well.

Punk rock bands concerned with violence in Central America provided their listeners with knowledge of current events and critical perspectives of U.S foreign policies. Concert tours had the same goal as Maximum RocknRoll - to promote truth and action to large audiences. The magazine hailed Toxic Reasons for traveling the U.S. to forge an underground punk rock circuit with the power to influence their audience's perspective on current events. ${ }^{41}$ Explaining their motivation in an interview with Maximum RocknRoll, the band members said, "If we are to have any influence on the power structures and they are to recognize this musical movement as significant, we must channel our thoughts and communications together to unite a growing national scene" and to that end called on readers "to be productive, support relevant bands, go to important rallies and support the underground media network." ${ }^{42}$ Witness testimonies inspired the creation of protest music, as well as the desire to use that music to mobilize the U.S. public.

In that vein, M.D.C. and Toxic Reasons, among others, went on "Rock Against Reagan" tours in 1983, 1984, and 1985. The tours were heavily promoted in Maximum RocknRoll with articles accompanied by ads for the music of participating bands, of which there were many; local bands often joined particular shows in support. ${ }^{43}$ In 1983, M.D.C. played over thirty-five cities with Rock Against Reagan. The musicians, in Dictor's words, "wanted people to know that there was a movement going on... That we had to change policies so we'd stop killing revolutionaries in Central America, so we'd stop killing nuns in El Salvador, we'd stop all the abuses that were going on around the world." 44 The bands on the tour used the

\footnotetext{
${ }^{37}$ David Dictor, interview with author, March 28, 2014.

${ }^{38}$ M.D.C., "Who's the Terrorist Now?" This Blood's for You, R Radical Records, 1987, MP3.

39 “Toxic Reasons,” Maximum RocknRoll 4 (January/February 1983), 13.

${ }^{40}$ Toxic Reasons, "How Do You Feel," Independence, Risky Records, 1983, MP3.

41 “Toxic Reasons," Maximum RocknRoll, 13.

${ }^{42}$ Ibid.

43 “Rock Against Reagan Tour '83," Maximum RocknRoll 6 (May/June 1983), 17.

${ }^{44}$ Dictor, interview with author.
} 
publicity and the music to get people involved in politics and political action. After the first round of tours, "all these other activists from around the country who wanted to rock against Reagan or wanted me to rock against Reagan" joined the tour as performers or audience members. ${ }^{45}$ During the tours, Dictor commented, even people who had not previously been exposed to punk rock "really started understanding that there was a lot more going on than punk rock and wearing spikey hair, breaking glass. There was a certain element in punk rock that was fighting for intelligent change." ${ }^{46}$ The musicians had to fight against misperceptions of punk rock music in order to make people understand not only their viewpoints, but also their particular messages about Central America. That they did during the tours, informing and mobilizing their audiences to become politically involved. Thus, the music of M.D.C. and Toxic Reasons, initially inspired by witness testimonies of human rights abuses in Central America, contributed to CAPSM by informing and mobilizing listeners through musical testimonies.

\section{Record Labels and 1980s Folk, Punk Rock, and Rock}

By working with smaller or independent record labels, punk rock artists like M.D.C. and Toxic Reasons could function without being constrained by commercial considerations, and historical developments did the same for folk artists like John McCutcheon and Peter, Paul and Mary. ${ }^{47}$ The ancestors of folk songs, the Civil Rights Movement's "freedom songs," did not themselves become commercially successful, but they did contribute to the emergence of a new type of popular artist that could be commercially successful: the folksinger. Folk singers followed African-American spiritual and blues artists in writing anthems for the Civil Rights Movement before turning to the student movement of the 1960s and 1970s to write songs protesting the militarization of the U.S. epitomized by the Vietnam War. Young people expressed an interest in authenticity as opposed to the mass commercialization of both consumer markets and military values. These principles translated into an interest in folk music, whose artists shared the same distaste for commercialization. ${ }^{48}$ Folk artists refused to "subordinate art to market demand," and for that they became not only popular, but also, ironically, commercially successful. ${ }^{49}$ Record labels saw profit in producing and distributing folk music because of the new market for it, and as a result, folk artists had "one foot in the streets and one in the market, telling it like it is, but still available through the commercial airwaves and on the largest record labels." ${ }^{50}$ Even with the decline in popularity of folk music with the rise of rock, folk artists retained their authenticity and continued creating music throughout the succeeding decades.

Changes in particular folk artists' styles to folk-rock and then to rock paralleled changes in student engagement from political protest to countercultural rebellion, and ultimately compromised the political freedom of rock artists. Sociologists Ron Eyerman and Andrew Jamison reason that rock's derivation from folk music offered the genre "commercial strength" and "cultural resonance." 51 Unlike folk, however, the

\footnotetext{
45 Ibid.

${ }^{46}$ Ibid.

${ }^{47}$ Peter, Paul and Mary's No Easy Walk to Freedom was released by Warner Off Roster; John McCutcheon's Water from Another Time was released by Rounder Records; M.D.C.'s This Blood's for You was released by R Radical Records; and Toxic Reasons' Independence was released by Risky Records.

${ }^{48}$ Ron Eyerman and Andrew Jamison, eds., Music and Social Movements: Mobilizing Traditions in the Twentieth Century (New York: Cambridge University Press, 1998), 118. https://doi.org/10.1017/CBO9780511628139.

${ }^{49}$ Rosenthal and Flacks, Playing for Change, 12.

${ }^{50}$ Ibid., 12-14.

${ }^{51}$ Eyerman and Jamison, Music and Social Movements, 108.
} 
commercial opportunities for rock music in the context of the disintegration of social movements in the 1970s led rock artists to assimilate into the very commercial culture that its ancestors had rejected. The financial success of rock on radio stations and of rock record labels meant that "new rules were imposed" for determining profitable genres, ones that were "no longer based on the counterculture's standards" and in fact were "not friendly to protests," according to sociologist Deena Weinstein. ${ }^{52}$

Mounting corporate control of music accessible to the public via radio, concert venues, and record production meant that artists of protest songs increasingly looked to radio stations, performance outlets, and record labels without the financial capital to warrant attention from mainstream media. ${ }^{53}$ This applied to both folk and punk rock protest music. The underground media promoting protest music, including record labels like R Radical Records and Rounder Records, as well as Maximum RocknRoll, could boast its own growing audience, but it could not access the majority of rock audiences or the general public. Artists of protest music had become dependent on these media to survive, but since the goal was to maintain authenticity rather than become financially successful, the artists refused to compromise. For Toxic Reasons, for example, making music was not about making money; it was about conveying a message. ${ }^{54}$

Rock, however, had become dependent on the commercial industry in the 1970s. The constraints imposed by private, corporate interests in the cultural market, based on their perception of protest music as unprofitable, meant that rock artists' freedom was restricted. ${ }^{55}$ Political scholar John Street writes that "the 'right' to be political can be granted and taken away by the organizations that produce popular music," as it had done when major record labels produced political folk music in the 1960s and turned away from it to apolitical rock music in the 1970 s. $^{56}$ The popularity of rock music coincided with a shift away from political protest to countercultural rebellion, which was characterized by a more vaguely utopic aim.

The resulting ambiguity and decreasing importance of the lyrics differentiated rock from folk. Folk music was marked by a focus on specific, first person lyrics, which artists often meant their audiences to sing in tandem, creating political positions in the listeners through the active identification with the narrative voice. Both John McCutcheon and Peter, Paul and Mary employed first person lyrics, in "No Más" and "El Salvador." Rock music rejected this narrative voice, as well as topical reference and lyrical specificity, in order to function in mainstream society. ${ }^{57}$ It therefore also contrasted with punk rock, which, as M.D.C. and Toxic Reasons did, employed lyrical specificity regarding the events against which the artists were protesting. Rock artists of the 1980s tended to build their commercial popularity on politically neutral music catering to the financial interests of big record labels.

\section{0s Rock}

In this context, being politically explicit constituted a risk. The fact that artists like U2 and Bruce Cockburn spoke out against U.S foreign policy in the 1980s illustrates how moved they were by their

\footnotetext{
52 Deena Weinstein, “Rock Protest Songs: So Many and So Few," in The Resisting Muse: Popular Music and Social Protest, ed. Ian Peddie (Burlington: Ashgate, 2006), 8.

${ }^{53}$ Weinstein, "Rock Protest Songs," 9.

54 “Toxic Reasons," Maximum RocknRoll no. 12 (March 1984).

${ }^{55}$ Rosenthal and Flacks, Playing for Change, 216. Peter, Paul and Mary in fact referenced this phenomenon in their one rock song, "I Dig Rock and Roll Music": "I dig rock and roll music / I could really get it on in that scene / I think I could say somethin' if you know what I mean / But if I really say it, the radio won't play it / Unless I lay it between the lines." Peter, Paul and Mary, "I Dig Rock and Roll Music," Album 1700, Warner Bros., 1967, MP3.

${ }^{56}$ John Street, "The Pop Star as Politician: From Belafonte to Bono, From Creativity to Conscience," in The Resisting Muse, 57.

${ }^{57}$ David James, “The Vietnam War and American Music,” Social Text no. 23 (1989), 127, 131, 134.
} 
exposure to human rights abuses in Central America. ${ }^{58}$ CAPSM prided itself on its ability to transmit testimonies from Central America to larger communities, and by doing so it inspired even commercially sensitive artists to risk financial instability with political music. After he traveled to El Salvador and Nicaragua with groups from Central American Missions Partners and Amnesty International, Bono wrote "Mothers of the Disappeared" and "Bullet the Blue Sky" for U2. He participated directly in CAPSM's strategy of witnessing conflict, and was moved accordingly. In El Salvador, he stayed with a group of guerillas in the northern part of the country. There, he met the Mothers of the Disappeared, "the courageous, outspoken collective of women that Archbishop Oscar Romero helped to organize in order to express grief and to publicize the disappearance of their family members." 59 Out of his experiences interacting with them came "Mothers of the Disappeared." He, like John McCutcheon, received and transmitted testimonies of violence to the U.S. public.

The lament for the sorrow of the mothers in this song contrasts with the anger directed toward the cause of that sorrow in "Bullet the Blue Sky." Although "Bullet the Blue Sky" is one of U2's most explicitly political songs and condemns the U.S. government for its intervention in El Salvador, the lyrics are not overtly direct. Phrases such as "In the howling wind comes a stinging rain / See it driving nails into the souls on the tree of pain / From the firefly a red orange glow / See the face of fear running scared in the valley below" populate the song, but a precise reference to El Salvador never surfaces. ${ }^{60}$ Music writer Dorian Lynskey divulges that Bono had brought to U2 "photographs and videos of the atrocities to inform the playing of the song, which he wanted to sound like 'hell on earth," but one of his band members advised him, "You'll ruin it for people if you give them images." ${ }^{61}$ U2 could minimize the risk of sacrificing popularity for politics by remaining less explicitly political in the lyrics and performances.

U2's protest music in response to U.S. interventions in Central America proved popular. The album on which "Mothers of the Disappeared" and "Bullet the Blue Sky" appeared, The Joshua Tree, topped Billboard Charts, earned spotlights in issues of the popular music magazine Rolling Stone, and sold enough albums to be certified at the highest levels by the RIAA.$^{62}$ Commentators in Rolling Stone hoped that similar music would "have the potential to organize a rock \& roll audience into an optimistic political body, or at least to provide the right information." 33 The magazine implied that political rock artists' success could inspire other artists to regain their political footing, and inspire listeners to become more political themselves. Indicating that its lyrics were explicit enough to be useful to CAPSM, U2's The Joshua Tree was also given several pages in Sojourners after its release. U2's songs were utilized by Sojourners to fortify its members' resolve to protest in solidarity with Central Americans. Bono's travels to Central America, too, then, resulted in musical testimonies valuable to CAPSM.

\footnotetext{
${ }^{58}$ Although U2 and Bruce Cockburn originated outside the U.S. (Ireland and Canada, respectively), their music became popular among U.S. citizens, they toured the U.S. to promote their music, and CAPSM organizations used their music to promote their cause, so their experiences are relevant.

${ }^{59}$ Dan Ouellette, “Outside America: U2's Songs of Survival,” Sojourners 16, no. 7 (July 1987), 43.

${ }^{60}$ U2, "Bullet the Blue Sky," The Foshua Tree, Mercury Records, 1987, MP3.

${ }^{61}$ Dorian Lynskey, 33 Revolutions per Minute: A History of Protest Songs, From Billie Holiday to Green Day (New York: HarperCollins Publishers, 2011), 384-385.

${ }^{62}$ Rolling Stone, a popular music magazine founded in 1967 by Jann Wenner, was and is known for its dual focus on politics and popular music. Its circulation levels at around 1.5 million. "Rolling Stone Media Kit," Rolling Stone, last modified December 31, 2012, accessed April 20, 2014, http://www.srds.com/mediakits/rollingstone/circulation.html. The RIAA is a trade organization that claims to represent the recording industry in the U.S.; its members produce 85 percent of all recorded music in the U.S. It established a reward program for albums with record numbers of sales.

${ }^{63}$ John Piccarella, "The Clash Drop the Big One: Red-Hot Rock \& Roll, a Joyful Noise and Politics that Live," Rolling Stone no. 338 (March 1981), 58.
} 
Bruce Cockburn also traveled to Central America and created protest music in response to that which he witnessed. On a trip sponsored by Oxfam in 1983, Bruce Cockburn traveled to Nicaragua and to a series of Guatemalan refugee camps located in Mexico. ${ }^{64}$ His brother had been working in solidarity with the Salvadoran guerillas and receiving and publicizing information about the conflicts in El Salvador and Nicaragua. ${ }^{65}$ Thus, Cockburn had heard testimonies of the effects of violence in Central America, but he needed to witness those effects for himself before he would act. Oxfam invited Cockburn and several other Canadian artists to travel to Nicaragua to "observe, using the relative visibility that we have to educate the Canadian public to what we had seen." ${ }^{66}$ Cockburn accepted the opportunity and entered the role of a witness in CAPSM's signal flare strategy.

Cockburn wrote songs such as "If I Had a Rocket Launcher" and "Nicaragua" in response to the devastation he witnessed in Nicaragua and the tales of terror he heard from the refugees in Mexico. He, unlike U2, did not refrain from political specificity in his protest music. In "Nicaragua," he sang "On the cliff the U.S. Embassy / Frowns out over Managua like Dracula's tower / [...] / In the flash of this moment / You're the best of what we are / Don't let them stop you now / Nicaragua." ${ }^{67}$ In these lyrics he references the U.S. government's violent disapproval of the Nicaraguan revolution, as well as a hope that the revolution would prevail despite U.S. aid to the contras. In testifying to specific current events through music, Cockburn considered himself more of a reporter than an activist, in line with CAPSM's conception of witness testimonies. ${ }^{68}$ He stated of "Dust and Diesel," another of his protest songs about Nicaragua, "All I did was make a list of things that happened and put it to music." ${ }^{69}$ His musical testimonies could inform the U.S. public of their government's actions while providing them with hope that, with determination and solidarity, the revolution in Nicaragua would outlast the war.

When asked why he had written these musical testimonies, Cockburn revealed that witnessing provided the primary motivation. He stated that his trip to Central America "was very sobering. I had seen refugee camps on TV, and I certainly always paid attention to certain military things and the facts of war were certainly familiar to me, but to be among people who you know were the victims of the brutality that was going on in Guatemala at the time was very deeply affecting." ${ }^{70}$ In fact, he told a Rolling Stone reporter that it was not until he went to Central America that he really felt that political action could be worth the effort. ${ }^{71}$ His mobilization reflects the success of CAPSM's work. His was the experience of witness that CAPSM determinedly worked to promote, knowing that seeing the consequences of U.S.-sponsored conflict in Central America could inspire action. After his trip, he worked tirelessly for peace in Central America, traveling there several more times, and making himself available for benefit concerts and other activities for CAPSM organizations.

Cockburn was not only inspired to report on what he had seen, but he was also inspired to call others to action. After visiting the refugee camps, he wrote "If I Had a Rocket Launcher," singing, "I want to raise every voice - at least I've got to try / Every time I think about it water rises to my eyes / Situation

\footnotetext{
${ }^{64}$ Richard Harrington, “The Long March of Bruce Cockburn: From Folkie to Rocker, Singing About Injustice,” The Washington Post, October 19, 1984, 7.

${ }^{65}$ Bruce Cockburn, interview with author, April 21, 2014.

${ }^{66}$ Harrington, "The Long March of Bruce Cockburn," 8.

${ }^{67}$ Bruce Cockburn, "Nicaragua," Stealing Fire, True North Records, 1984, MP3.

${ }^{68}$ Cockburn, interview with author.

${ }^{69}$ William Ruhlmann, "Bruce Cockburn - A Burning Light and All the Rest,” Goldmine Magazine, April 3, 1992.

${ }^{70}$ Cockburn, interview with author.

${ }^{71}$ Steve Pond, "Bruce Cockburn Launches a Hit: Fired by Christian Pacifism, the Canadian Singer Targets New, Worldwide Success,” Rolling Stone no. 448 (May 1985), 22.
} 
desperate, echoes of the victims cry / If I had a rocket launcher, some son of a bitch would die." ${ }^{\text {2 }}$ He asked listeners to mobilize in response to the violence, relating his own testimony and using it to inspire action by others.

Rock protest music in the 1980s not only represented a revival of politics in rock music, but it also had the benefits of commercial success and influence on social movements. Even Cockburn's politically charged songs were popular in the U.S., stealing prime spots on Billboard Charts for multiple weeks. ${ }^{73}$ The placement of record reviews and interviews with Cockburn in Rolling Stone and in prominent newspapers like the New York Times also indicates the prestige garnered by his new releases. CAPSM organizations, too, saw value in Cockburn's music and put it to use. Sojourners published several articles about Cockburn's songs throughout the 1980s. The magazine publicized them as examples of "passionate involvement with the people of Central America" and praised Cockburn for his optimism in the face of a world filled with oppression. ${ }^{74}$ Sojourners emphasized the connections between Cockburn's Christianity and the politics of his songs - the combination with which they sought to engage their readers, and the activists in the movement. The anger Cockburn conveyed in "If I Had a Rocket Launcher," paired with the optimism of his other music, promised readers of Sojourners that a better world might yet be born. Sojourners declared of Cockburn's music in particular, “...in these jubilant notes of hope as well as anger, we rejoice and struggle on." ${ }^{75}$ CAPSM organizations saw the potential of Cockburn's musical testimonies to mobilize the U.S. public.

\section{Protest Music as Uniquely Effective}

Once the folk, punk rock, and rock protest music of the 1980s came into existence, it was able to reach a wide audience with a particular type of testimony about U.S. foreign policy. Whereas the inspiration for particular artists' protest music indicated the effectiveness of CAPSM's witness strategy, the popularity of the music and the use of the music by the movement's composite organizations indicated the music's effectiveness as a tool of CAPSM.

The power of musical testimonies to mobilize U.S. citizens in general, though, originates in the combination of the explanatory lyrics of the music and the unifying, emotional experience of listening to the music in a group setting. Stookey considers that "The closest thing to a common experience of emotion is music...when you add coherent thought or articulation of behavior [the lyrics] to music, you can lead a learning moment." In this context, "music can draw you to want to change the world around you, especially after singing with the musician and you come to desire what the lyrics call for." 76 The power of music to convey and create a shared understanding of experience is rooted in its words as well as its sounds, and thus it is unique among the art forms in inspiring shared experience. Protest music invites and unites participants in a social movement by articulating a particular perspective on society. Artists of protest songs "do more than just acquaint an audience with certain ideas and perspectives," though "they're hoping to win us over to those ideas, to engender commitment to a perspective and the group that holds that perspective." 77 The call to action explicitly stated in the lyrics or implied in the music of a

\footnotetext{
${ }^{72}$ Bruce Cockburn, "If I Had a Rocket Launcher," Stealing Fire, True North Records, 1984, MP3.

${ }^{73}$ Billboard Charts are lists of popular songs; popularity is determined by radio airplay, record sales, and the like.

${ }^{74}$ Mark Gornik, “Liberating Rhythms: Bruce Cockburn's Journey on Record,” Sojourners 16, no. 11 (December 1987$), 41$.

${ }^{75}$ Gornik, "Liberating Rhythms," 43.

${ }^{76}$ Stookey, interview with author.

${ }^{77}$ Rosenthal and Flacks, Playing for Change, 157.
} 
protest song can bind an individual to a particular cause, and inspire that individual to participate in protest to the fullest extent possible, despite the risks.

Social movements used music as a distinctive means of shared experience and identity to solidify commitment, educate, recruit, and mobilize members in the Civil Rights Movement of the 1950s, the student movement of the 1960s-1970s, and CAPSM of the 1980s. During the Civil Rights Movement, civil rights activists sang together during acts of civil disobedience. As music became intertwined with the movement, it was charged with a new responsibility. The music articulated a new vision of U.S. society, and that vision contributed directly to the folk revival inspired by the music of the Civil Rights Movement. ${ }^{78}$ In the 1960s, folk artists drew on the example of the Civil Rights Movement by promoting a culture of participatory democracy exemplified by its own acceptance of amateur musicians with a message. Music provided youth in the 1960s with "a basis of common understanding and common experience for a generation in revolt," as it had done for African-Americans and white Americans in the Civil Rights Movement. ${ }^{79}$ Some scholars argue that 1980 s rock discontinued this trend, partially because of the lack of a common cause. For instance, Weinstein argues that "one reason for the paucity of rock protest songs is the absence of mass protest movements during most of rock's history." ${ }^{80}$ Yet, the U.S. interventions in Central America offered rock artists an issue around which to mobilize. Thus, the crossgenre music of CAPSM continued the tradition of musical protest.

\section{CAPSM's Success}

John McCutcheon, Peter, Paul and Mary, M.D.C., Toxic Reasons, U2, and Bruce Cockburn may have represented different musical genres, performed in different venues, and boasted different audiences, but their music had in common an origin with CAPSM's witness strategies and a service to the movement in return. Their music helped to educate and mobilize U.S. citizens, as the organizations that put their music to use revealed. The organizations of CAPSM hoped that witness testimonies would educate and mobilize a wider public. With the aim of measuring the impact of the signal flare strategy on public opinion, Perla analyzed letters from U.S. citizens to President Reagan and concluded that CAPSM was uniquely effective in disseminating information. ${ }^{81}$ Letters in opposition to his administration's foreign policies "highlight the powerful role of Central Americans' personal testimonios and the vital role of amplification played by human rights organizations" by demonstrating a deep understanding of the conflicts, actors, and victims, and by citing sources with strong links to Central America, such as religious organizations working with the poor. ${ }^{82}$ Thus, CAPSM effectively utilized witness testimonies as tools of education and mobilization - informing the U.S. public of the complex realities of the violence in Central America, and prompting them as tax-paying U.S. citizens to pressure their government to alter its foreign policies. Musical testimonies were part of that process, framing the events in Central America in such a way that they promoted an alternative understanding of U.S. foreign policy to the one promoted by the government itself.

CAPSM was unique in terms of its organizing strategies and effectiveness in mobilizing musicians to

\footnotetext{
${ }^{78}$ Eyerman and Jamison, Music and Social Movements, 77, 109.

${ }^{79}$ Ibid., 138.

${ }^{80}$ Weinstein, "Rock Protest Songs," 8.

${ }^{81}$ Hector Perla Jr., "Central American Counterpublic Mobilization: Transnational Social Movement Opposition to Reagan's

Foreign Policy Toward Central America," Latino Studies 11, no. 2 (2013), 180.

${ }^{82}$ Perla, "Central American Counterpublic Mobilization," 184.
} 
action, but its use of protest music continued a practice of social movements since the Civil Rights Movement. Music in the service of social movements, as summarized by Rosenthal and Flacks, provides analysis of social issues, disrupts basic assumptions about societal inevitabilities, organizes listeners' understanding of the world, develops collective identities and evokes solidarity, creates a space for listeners' emotional and cognitive growth, and generates energy. ${ }^{83}$ U.S. interventions in Central America offered artists a new issue around which to mobilize: human rights. Folk, punk rock, and rock musicians were each motivated by the witness testimonies they read or by their travels to Central America, and decided to act. They came together in one movement to declare, "No más! No more!" The precise effectiveness of their declarations cannot be measured, but their influence can be surmised, especially with the help of the organizations that saw value in their songs and utilized them to build their support.

\section{An End to CAPSM?}

The current activities of the organization School of the Americas Watch (SOAW), rooted as they are in 1980s protests against U.S. support of violence and oppression in Latin America, call into question the terminus of CAPSM and its tradition of music in service to social movements. Numerous human rights abusers in Central America had been trained at the U.S. School of the Americas (SOA) in Fort Benning, GA, and thus the school itself became a target of protest. ${ }^{84}$ Roy Bourgeois, a priest from Syracuse, infiltrated the SOA base at Fort Benning early one morning in 1991 and rigged up speakers to blast a recording of the last homily of Archbishop Romero, in which he had called on the military and paramilitary soldiers in El Salvador to lay down their arms. Bourgeois's act of civil disobedience and trespassing would earn him two years in jail, but it would also spark the founding of SOAW. SOAW has continued to protest U.S. financial and military support of oppressive regimes and repressive military units in Latin America, an issue at the forefront of the CAPSM in the 1980s.

SOAW has also similarly embraced the relationship of protest music to the effectiveness of social movements. Folk singer Colleen Kattau became politicized by the actions of SOAW and found that at SOAW rallies, music takes center stage. Kattau became a part of the core of musicians who perform for and lead crowds in musical protests. She recorded her album Sing it Down: Songs to Close the School of the Americas in 1999 to educate listeners, draw them into the movement, prompt them to think about alternatives to war and violence, and thereby create a collective consciousness. ${ }^{85}$ She believes that music is not only a tool for the movement, but it also has the power to engender hope by becoming a means of human expression in times of hardship. ${ }^{86}$ As the music is performed at SOAW rallies, she sees it resonate with protesters - she has witnessed music create meaning for the movement, solidify the profundity of nonviolence, and bring protesters to an emotional summit at which tears run down their faces. ${ }^{87}$ SOAW holds regular concerts and sells copies of Sing it Down to raise money, demonstrating that the organizers understand the power of music within the movement. Sandy O of emma's revolution, another core SOAW performer, said in an interview, "Not all movements understand the importance of music the way

\footnotetext{
${ }^{83}$ Rosenthal and Flacks, Playing for Change, 114-118.

${ }^{84}$ Lesley Gill, The School of the Americas: Military Training and Political Violence in the Americas (Durham: Duke University Press, 2004). https://doi.org/10.1215/9780822386001.

${ }^{85}$ Colleen Kattau, interview with author, January 3, 2014.

${ }^{86}$ Kattau, interview with author.

${ }^{87}$ Ibid.
} 
the SOA Watch does." 88 Many observers believe that the SOAW's grasp on "harnessing music's ability to affect us emotionally and move us through emotional levels" is the reason that the movement "has lasted for 15 years and has been so successful." ${ }^{\prime 9}$ The power of music to mobilize has once again been consciously engaged in the service of a social movement. Thus, the legacy of music for social change, begun in earnest with the Civil Rights Movement of the 1950s, lives on.

\begin{abstract}
The U.S.-Central American Peace and Solidarity Movement (CAPSM) of the 1980s inspired cross-genre creation of new protest music in a decade often characterized by its apathy. I argue that this music and its place in the movement continued the tradition of protest music in service to social movements in the 1950s, 1960s, and 1970s. However, this music was uniquely integral to CAPSM because its creation reflected the effectiveness of the movement's organizing strategy of using witness testimonies, and the songs in turn became "musical testimonies" that could educate and mobilize a large audience. This paper examines the music of several folk, punk rock, and rock artists whose experiences exemplify the importance of protest music to the success of CAPSM in organizing one hundred thousand U.S. citizens in response to U.S. interventions in Central America, especially in El Salvador, Guatemala, and Nicaragua, during the 1980s.
\end{abstract}

${ }^{88}$ Carole Ferrari, "Please Remember Music: Songs Play a Central Role at the School of the Americas Protest," The Dominion: News from the Grassroots, January 10, 2006, 8, http://www.dominionpaper.ca/arts/2006/01/10/please_rem.html.

${ }^{89}$ Ferrari, "Please Remember Music," 8. 